\title{
The Columbia University Libraries
}

\section{Self-Study}

$\mathrm{T}$ HIS BRIEF report $^{1}$ on the self-study of the Columbia University Libraries will be concerned primarily with the purposes, general methodology, and devices used in measuring adequacy. Since the report is at present being readied for publication by the Columbia University Press, ${ }^{2}$ it does not seem appropriate at this time to discuss in detail conditions and conclusions, although reference to some findings will be made at various points.

\section{Purposes}

The study developed from the proposal of the Director of Libraries, in May, 1956, that the President's Committee on the Educational Future of the University include in its self-study of current and prospective institutional problems those relating to the University Libraries. At a meeting in May, the Director of the President's Committee had indicated that it had been thought that the Libraries represented a complex problem that would require the assistance of a subcommittee. Authorization for the library study was made in June, 1956, and the subcommittee consisted of Richard H. Logsdon, Director of Libraries, C. Donald Cook, an associate of the School of Library Service, and your reporter. I was relieved of my teaching duties for the fall semester of

\footnotetext{
1 Paper presented at the Eastern College Librarians Conference, Columbia University, November 30, 1957.

2 Planned for publication in summer, 1958.
}

Dr. Tauber is Melvil Dewey Professor of Library Service, Columbia University.
1956; Mr. Cook worked half-time with me, since he was teaching one of my courses. We had a full-time secretary. Although February 1, 1957, was the given deadline, many problems arose which made it necessary to extend this deadline to April 1. This was not a serious delay, since the parent committee had met delays which coincided. However, it meant that both Mr. Cook and myself found ourselves with other obligations as well as the completion of the report. We were under considerable pressure most of the time, and we ran into some difficulty with the questionnaires which we used because of the relatively short time available to us.

It was decided by the members of the subcommittee, after meeting with the President's Committee, that it would be necessary not only to include but also to go beyond the observations and records of the staff of the University Libraries in evaluating the Libraries' resources, facilities, and services. That is, one of the major purposes of the study was to involve the administration and faculties, as well as the students, in the question of library service. It was evident in the discussions with the President's Committee that the members considered the $\mathrm{Li}$ braries an integral part of the instructional and research program of the University.

\section{Methodology}

The methodology of the survey or self-study followed common devices of examination used in similar studies in the past. Questionnaires, interviews, group discussions, visits, requests by tel- 
ephone and correspondence, analyses of documents and records for historical and statistical purposes, and special reports prepared by various personnel were employed. There was no special effort made to compare Columbia with other libraries, although reference is made to Columbia's gradual loss of rank in terms of annual library expenditures.

The battery of questionnaires used probably was as formidable as any ever employed in a university library study. Included were: (1) interview schedule for deans, directors, and other executive officers, (2) questionnaire to faculty members, (3) questionnaire to library departmental heads, (4) questionnaire to library staff members, (5) questionnaire to graduate and professional school students, (6) questionnaire to undergraduate students, (7) a letter-questionnaire to a group of New York City librarians on matters relating to cooperation.

The director of the survey interviewed deans, directors, and other executive officers or their representatives concerning their plans for the development of curricula and research programs for the future. In preparation for the interviews with executive officers, a checklist of points to be considered was prepared and distributed prior to the meetings. A number of the executive officers filled these forms out for the subcommittee, but in most cases they served primarily as a basis for discussions relating to the department, school, institute, or other unit of the University in relation to the Libraries in terms of present or future problems. In a few cases, executive officers had chairmen of the library committees or library representatives for the particular units present at the meeting. The checklists were particularly useful in stimulating the discussions. Essentially, the schedule includes observations on problems of enrollment affecting library service (changes in character of student body, proportion of resident to commuting students, number of part-time students, including evening students, and foreign students), changes in faculty affecting library service (size, type of activity-instructional, research, clinical, etc.-utilization of fellows, teaching assistants, research assistants), changes in curriculum and research programs (course structure, kinds of problems likely to be studied, doctoral and post-doctoral research, governmental contracts, other contractual relationships), relation of unit to library program (committee and individual faculty member action), need for special (departmental) library resources, quarters and equipment, courses in the use of the libraries, attitudes toward cooperative enterprises, collecting policy of the future, suggestions concerning library program, and observations on any special problems involving library resources or services.

In so far as possible, the chairman of the subcommittee visited the executive officers and faculty members in their own quarters. This was done deliberately. It provided the chairman with an opportunity to see how the personal libraries of deans, directors, and faculty members were developing. In the large university, such as is represented by Columbia, there is some inclination on the part of faculty members and administrative officers to build up large personal collections. This may have some direct effect upon their attitudes toward the libraries. In some cases, they seldom visit them, even their departmental libraries. In other instances, they have little idea of the many problems facing the library personnel. They cannot always understand their students' problems, particularly when there is a shortage of copies or materials. They lend students materials, rather than approach the libraries. It would be difficult to estimate the number of volumes in the offices of non-library personnel at Columbia, but there are any number which run into several thousands of volumes. In numerous instances, faculty members have 
even larger collections of materials at home.

A total of 143 individuals representing the administration or the faculty was interviewed. While the chairman was interviewing, the associate proceeded to develop the questionnaires to be used in obtaining information from the other groups. Drafts of these questionnaires, as well as the interview schedule for administrative officers, were reviewed by the President's Committee, the supervising librarians, and the Director and Assistant Director of Libraries. After changes were made, the questionnaires were tested with individuals in the groups for which they were intended. They were distributed during November and December, 1956.

On the whole, the questionnaires served well in providing the information desired. However, because of the pressure of time, the percentage of returns which could be tabulated was not always as high as had been hoped for. Of the 2,250 questionnaires sent to faculty members, including part-time faculty and clinical professors, 709 were returned when the tabulations were closed; of these, 644 could be used. Of the 1,500 forms sent to undergraduate students, 395 were used; of the 2,000 sent to graduate and professional school students, 355 could be used; of the 274 sent to the 1956 Ph.D. graduates, 91 were used; all departmental librarians returned their questionnaires; of the 256 forms sent to all full-time library staff members, 109 were used. The questionnaire to 23 librarians in metropolitan New York concerning matters of interlibrary cooperation was returned by 22 individuals.

It may appear from these figures that the returns were inadequate for our purposes. We do not believe so, at least for most of the questions which we were trying to answer. In respect to resources, a basic problem, it will be necessary to pursue this further, since individual re- actions to collecting policies are sought. Mr. Cook will study this problem in more detail as a doctoral investigation in the School of Library Service.

I should mention that since the survey was closed in respect to questionnaires, we have received a large number of faculty replies. These will be used by Mr. Cook in his analysis of the relation of the faculty to the building of library collections.

One general question of methodology which might be raised in connection with this survey is concerned with the estimate of objectivity. Were not the individuals associated with the study so close to the Libraries that it would not be possible for the members to be objective in recommendations? The selfstudy, of course, may have certain limitations in this respect. It should be remembered, however, that the general study by the President's Committee was basically self-study, even though outside consultants were used and visits were made to other universities. In the use of standards and general principles of university library administration, it may be said that the subcommittee, as well as the supervising librarians who worked closely with the study during its entire period, were constantly critical and bent over backwards in trying to attain objectivity. Undoubtedly, there are some observations which might have occurred to outsiders and which might have escaped the attention of persons associated with the particular institution. It might be said in this connection, however, that the President's Committee was rigorous in its concern about questionnaires and the general structure of the survey. In so far as self-surveys are likely to be introspective, I suspect that the Columbia Libraries survey may have suffered somewhat. From my knowledge of surveys of other libraries, however, I would guess that the suffering would be minimal. 


\section{Devices for Measuring AdeQuacy}

One of the great difficulties in evaluating a library is to measure needs and services. What does an institution need in terms of service? What kinds of services should the libraries provide? How does one measure book collections, budgets, catalogs, and classification systems or reference service and other activities of the library? Why are buildings, or library quarters, inadequate?

In the development of the self-study, a total of 165 questions were evolved which were concerned with the various parts of the library service-administrative organization, resources, cataloging and classification, quarters, equipment, preservation of materials and photoduplication, personnel, readers' services, interlibrary cooperation, and financial support. These questions were reviewed as to their efficacy in providing a basis for drawing conclusions on the ten questions which formed the basis of the study. Many of these questions are answered in the survey. Others require more minute studies which should be made during the next decade, unless there are developments in librarianship which will change the patterns which we follow today. It may be worth reviewing these areas in terms of instruments of measurement.

Administrative Organization. How does one measure administrative organization? The existence of organizational charts to show relationships is but a simple start. The history of Columbia University Libraries in respect to its administrative organization has been one of considerable change since 1943. The pattern has been altered three times in major administrative posts. The present structure of supervising librarians, developed on the basis of subject or physical units (e.g., the law librarian, or the librarian of the physical sciences), has proved successful for the present. The general, centralized system of the $\mathrm{Li}$ - braries, with the exception of the affiliated institutions, likewise has been regarded by the university and library administrations as effective and worth retaining. Through meetings held regularly, memoranda, and direct contact, the supervising librarians work closely with the director and assistant director in carrying on the work of the Libraries. In response to specific questions on the general pattern of the library administration, there were no serious suggestions that any unit of the Libraries be given completely independent authority. Such special needs as separate acquisition or cataloging units, which exist in the law and medical Libraries, have been met when necessary. This is also true for local cataloging units for music and East Asiatic libraries, for indexing in the Avery architectural library, and for similar operations.

In regard to communications within the libraries and from the libraries to the administration, and vice versa, it was observed that although there were efforts to communicate freely, important lapses have occurred in both respects. The creation of a Library Committee of the University Council in 1951 led to improved communications. This has been furthered by the inclusion of the Director of Libraries on the President's Committee on Educational Policy.

Resources. How does one measure the resources of a Library? In surveys of libraries which have been made in American university libraries, there has been a common pattern of evaluating holdings through such measurements as (1) checking the resources against bibliographies in separate subject fields, (2) seeking faculty opinions on the strengths and limitations of collections, (3) examining users' difficulties in obtaining materials needed for course work and research, and (4) measuring the collections against the holdings of other research libraries in the country. The volume by Robert B. Downs, The Resources of $\mathrm{Li}$ - 
braries of New York City, issued in 1937, contains considerable information about the holdings of the Columbia Libraries, among the other libraries in the city. Although out of date, it provides a preliminary guide to the collecting directions of the Columbia Libraries, which have been acquiring materials on a world basis to meet the needs of instruction and research.

In the Columbia survey, we did not check bibliographies specifically for information. This does not mean that departmental librarians have not used bibliographies as guides in the development of collections. This practice has been an automatic procedure of the Libraries, and the items in the desiderata file in the acquisitions department represent either the lack of funds or the inability to obtain items at reasonable prices.

It was learned from interviews and from other sources of information-departmental librarians and faculty members themselves (in questionnaires)that there was room for improvement on the part of the faculty in the development of resources. The assumption held that faculty members were largely responsible for the development of the collections was sorely tested in the Columbia survey. Despite this failure in many respects, it must be said that the faculty members who do participate in selection jealously guard this right, and indeed there was a strong feeling that publicity should be given to the amount of book funds allotted to different departments.

Faculty opinions regarding the resources were obtained on a wide scale through a separate section of a faculty questionnaire. Many of the individual faculty members did remarkable jobs in analyzing their collections from the point of view of level of collecting: (I) basic information collection, collect materials on a limited basis in fields not covered in curriculum (agriculture), (2) a working collection, which is adequate to determine current knowledge in a sub- ject in broad outline and support undergraduate courses, (3) a general research collection, which contains materials adequate to the needs of graduate students of the subject, (4) a comprehensive collection, which goes beyond the general research collection in depth and types of materials, language, and period of time covered, (5) exhaustive collection, which attempts to gather all materials on the subject.

The report provides a detailed section, worked out by William L. Williamson and Erle Kemp, of the Libraries staff, of the reports of the faculty members on their respective fields.

The departmental librarians were asked to evaluate the collections in much the same way as the faculties. There was an extremely high correlation between the evaluations of the departmental Iibrarians and those of the faculty members. It might be assumed that this was to be expected and that the librarians oriented the faculty members in the deficiencies and strengths in the collections. This is perhaps true to some extent. The point might well be made, however, that the faculty members at Columbia are highly individualistic and are independent in their views. In most of the reports from several members of a teaching department there was a common reaction to the status of the collections. There is no hiding of the fact that certain collections at Columbia are weak and that present funds are not permitting the proper development of them.

One of the ways in which the subcommittee attempted to evaluate the collections was through the questioning of all - except two- of the Ph.D. graduates of 1956. Columbia offers the Ph.D. degree in forty-nine different fields, and arrangements may be made to take the degree in other fields. In addition, doctoral degrees are awarded to professional students in seven additional fields (science of law, medical science, public health, education, engineering science, 
social welfare, and library science). It was found that Columbia was able to provide source materials for 90 per cent of the students (ninety-one answered during the period provided, although several other forms came in later) who responded. What was evident in the responses was the wide range of libraries in New York City and elsewhere-including foreign countries-used by the doctoral students in the development of their dissertations.
Other Areas.--Various approaches were made to problems dealing with cataloging and classification, quarters, equipment, preservation of materials, photoduplication, personnel, readers services, interlibrary cooperation, and finance. These are spelled out in some detail in the published volume and cannot be discussed in this brief report. It should also be noted that the several questionnaires used in the study are included in the volume.

\section{H.R. 10381}

At the college level we must provide library service to meet the needs not only of an enormously increased enrollment but also of the revolutionary new demands for study and research in science, languages, and other rapidly widening fields. The great research libraries must be strengthened in their holdings, their bibliographical services, and their ability to make instantly available to American scientists the results of foreign, as well as domestic, research. It is in these libraries that much research begins. ...

The library is the intellectual laboratory of every school system-of the sciences, the social sciences, the humanities, the fine arts. It is in many ways the nerve center, the communications center of the vital intellectual functions of a school, college, or university. Because of the increasingly complex nature of our educational structure, and in the face of the increasing demands of growing student bodies, libraries need more support than ever before. Any scholarship program, any research program, any increase in enrollment, any widening of collegiate functions causes comparable increases in the demands on college libraries and on their use.

The amount and complexity of printed and other materials produced which must be systematically acquired, processed, and retrieved for use by the student and research worker, demand increased skills and training. It would indeed be tragic if there were support on a national level for the subject fields, especially science and technology, without accompanying effort to train sufficiently the necessary number of librarians needed to collect, organize and produce on demand these materials. To be able to meet satisfactorily the continuing national emergency, greater numbers of more highly trained librarians must be forthcoming. The field of library science is not a large one, but even percentage-wise there are pitifully few scholarships available at the present time.

As the nation and the states move to strengthen the educational foundations of our security and freedom, it is imperative that the country's need for libraries and their services at all levels of education be fully recognized and adequate provision be made for their support.-Part of a statement by Germaine Krettek, director of ALA's Washington office, on H.R. 10381 before the House Subcommittee on Education. 